\title{
ANALISIS RISIKO PENULARAN FILARIASIS LIMFATIK DI KABUPATEN ACEH UTARA
}

\author{
Rizka Sofia $^{2}$, Cut Sidrah Nadira ${ }^{2}$ \\ ${ }^{1}$ Bagian Parasitologi, Fakultas Kedokteran, Universitas Malikussaleh \\ ${ }^{2}$ Bagian Mikrobiologi, Fakultas Kedokteran, Universitas Malikussaleh
}

Corresponding author: drrizkasofia@gmail.com

\begin{abstract}
Abstrak
Filariasis limfatik merupakan penyakit menular menahun yang disebabkan oleh cacing filaria dan ditularkan oleh nyamuk Mansonia, Anopheles, Culex, dan Armigeres. Jumlah kasus filariasis di Kabupaten Aceh Utara pada tahun 2017 mengalami peningkatan menjadi 103 kasus. Tujuan penelitian ini yaitu untuk menganalisis faktor risiko penularan filariasis limfatik di Kabupaten Aceh Utara. Jenis penelitian yang digunakan merupakan penelitian retrospektif dengan desain studi kasus kontrol. Jumlah sampel penelitian ini sebanyak 134 orang yaitu 67 orang untuk kelompok kasus dan 67 orang kelompok control. Metode analisis data yang digunakan meliputi analisis Chi-Square. Hasil analisis bivariat menunjukkan bahwa variabel penelitian yang mempunyai hubungan dengan kejadian filariasis limfatik di Kabupaten Aceh Utara yaitu kebiasaan menggunakan kelambu $(\mathrm{P}=0,001$, dan $\mathrm{OR}=5,82)$, Kebiasaan menggunakan obat anti nyamuk $(\mathrm{P}=0,001$ dan $\mathrm{OR}=3,43)$, kebiasaan menggantung pakaian di dalam rumah $(\mathrm{P}=0,042$ dan $\mathrm{OR}=4,92)$, penggunaan kawat kasa ventilasi rumah $(\mathrm{P}=0,001$ dan OR 3,71), dan variabel kondisi plafon rumah $(\mathrm{P}=0,014$ dan $\mathrm{OR}=5,18)$. Hasil analisis multivariat didapatkan hanya empat variabel yang menjadi faktor risiko penularan filariasis limfatik di Kabupaten Aceh Utara, yaitu penggunaan kelambu, penggunaan kawat kasa, menggantung pakaian, dan plafon rumah.
\end{abstract}

Kata Kunci: perilaku; filariasis limfatik; lingkungan fisik; faktor risiko

\section{Risk Analysis Of Limfatic Fiariasis Transmission In North Aceh District}

\begin{abstract}
Lymphatic filariasis is a chronic infectious disease caused by filarial worms and transmitted by Mansonian, Anopheles, Culex, and Armigeres mosquitoes. The number of cases of filariasis in North Aceh District in 2017 has increased to 103 cases. The purpose of this study is to analyze the risk factors for lymphatic filariasis transmission in North Aceh Regency. This type of research is a retrospective study with case control study design. The number of samples of this study were 134 people, 67 people for the case group and 67 people for the control group. Data analysis methods used include Chi-Square analysis. The results of the bivariate analysis showed that the research variables that were related to the incidence of lymphatic filariasis in North Aceh District were the habit of using mosquito nets $(\mathrm{P}=0.001$, and $\mathrm{OR}=5.82)$, the habit of using anti-mosquito medication $(\mathrm{P}=0.001$ and $\mathrm{OR}=3.43)$, the habit of hanging clothes inside the house $(\mathrm{P}=0.042$ and $\mathrm{OR}=4.92)$, the use of home ventilation gauze wire $(\mathrm{P}=0.001$ and $\mathrm{OR} 3.71)$, and the ceiling condition variable of the
\end{abstract}


house $(\mathrm{P}=0.014$ and $\mathrm{OR}=5,18)$. The results of multivariate analysis showed that only four variables became risk factors for lymphatic filariasis transmission in North Aceh District, namely the use of mosquito nets, the use of wire mesh, hanging clothes, and the ceiling of a house.

Keyword: behavior; lymphatic filariasis; physical environment; risk factor

\section{PENDAHULUAN}

Filariasis limfatik (penyakit kaki gajah) adalah penyakit menular menahun yang disebabkan oleh cacing filaria dan ditularkan oleh nyamuk Mansonia, Anopheles, Culex, dan Armigeres. Cacing tersebut hidup di saluran dan kelenjar getah bening dengan manifestasi klinik akut berupa demam berulang, peradangan saluran dan saluran kelenjar getah bening. Manifestasi klinis pada stadium lanjut dapat menimbulkan cacat menetap berupa pembesaran kaki, lengan, payudara dan alat kelamin. ${ }^{1}$ Jenis spesies cacing filaria penyebab filariasis limfatik yang paling sering adalah Wucheria brancofti, sedangkan jenis spesies cacing filarial untuk negara bagian Asia yang paling banyak adalah Brugia malayi, dan Brugia timori. ${ }^{2}$

Data dari World Health Organization (WHO), diperkirakan 120 juta orang di dunia terinfeksi penyakit filariasis, terutama negara-negara di daerah tropis dan subtropis. Jumlah dari keseluruhan penderita, terdapat 25 juta penderita laki-laki mengalami penyakit genital (umumnya menderita hydrocele) dan hampir 15 juta orang, kebanyakan wanita, menderita lymphoedema atau elephantitis pada kakinya. ${ }^{3}$ Sampai dengan tahun 2014, di Indonesia terdapat lebih dari 14 ribu orang menderita klinis kronis filariasis (elephantiasis) yang tersebar di semua provinsi. Secara epidemiologi, lebih dari 120 juta penduduk Indonesia berada di daerah yang berisiko tinggi tertular filariasis. Sampai akhir tahun tahun 2014, terdapat 235 kabupaten/kota endemis filariasis, dari 511 Kabupaten/kota di seluruh Indonesia. ${ }^{4}$ Provinsi Aceh merupakan salah satu wilayah endemis dengan 21 dari 23 kabupaten/kota yang merupakan wilayah endemis filariasis berdasarkan hasil pemetaan survei darah jari yang dilakukan oleh Dinas Kesehatan setempat pada tahun 2009 dan 2013. Data dari Dinas Kesehatan Provinsi Aceh pada tahun 2015 mencatat jumlah kasus klinis filariasis yang di laporkan sebanyak 455 kasus. ${ }^{5}$ Jumlah kasus ini merupakan jumlah kumulatif yang di laporkan dari waktu ke waktu, baik penderita lama maupun penderita yang baru. Tahun 2015, Kabupaten Aceh Utara ditemukan 41 kasus filariasis dan terus mengalami peningkatan. Data terakhir dari Dinas Kesehatan Kabupaten Aceh Utara pada tahun 2017, jumlah penderita kasus filariasis menjadi 103 kasus. $^{6}$

Penyakit filariasis dapat terjadi apabila ada lima unsur utama yaitu sumber penularan, parasit, vektor, manusia yang rentan, dan lingkungan. ${ }^{7}$ Penularan penyakit dalam segitiga 
epidemiologi dikemukakan hal tersebut dapat terjadi karena adanya interaksi antara inang, agen, dan vektor. ${ }^{8}$ Berdasarkan penelitian sebelumnya oleh Windiastuti et.al tahun 2013 didapatkan bahwa perilaku tidak menggunakan obat anti nyamuk dan kebiasaan keluar rumah malam hari mempengaruhi kejadian filariasis. Seseorang yang tidak menggunakan celana dan baju panjang dan kebiasaan tidur tidak memakai kelambu juga mempengaruhi kejadian filariasis. $^{9}$

Lingkungan sangat berpengaruh terhadap distribusi kasus filariasis dan mata rantai penularannya, baik itu lingkungan fisik, biologik, ataupun sosial budaya. Lingkungan fisik mencakup keadaan iklim, fisik rumah, dan struktur geologis berkaitan dengan kehidupan vektor, sehingga berpengaruh terhadap munculnya sumber-sumber penularan filariasis. Vektor utama filariasis suatu daerah berbeda dengan daerah lain, tergantung dari kondisi lingkungan dan jenis cacing parasitnya. Jenis spesies vektor penular filariasis terbanyak di propinsi Aceh adalah Culex quinquefasciatus, Mansonia uniformis, dan Mansonia Indiana. ${ }^{4}$

Perilaku masyarakat Aceh yang sering keluar pada malam hari, baik untuk urusan pekerjaan ataupun untuk sekedar duduk di warung kopi sebagai salah satu tradisi yang diwariskan secara turun temurun, bisa menjadi salah satu faktor yang mempengaruhi kejadian filariasis. ${ }^{10}$ Selain itu faktor keadaan fisik rumah di Kabupaten Aceh Utara juga berpengaruh karena keadaan rumah yang tidak memenuhi syarat sehat bisa menjadi faktor tempat muncul dan berkembangnya vektor filariasis. Berdasarkan data dari Dinas Kesehatan Aceh Utara dikatakan bahwa jumlah dan persentase rumah sehat di Kabupaten Aceh Utara tahun 2016 adalah sebanyak 37893 rumah atau $29 \%$ dari 12.747 rumah yang dibina. ${ }^{6}$

\section{METODOE}

Penelitian ini dilakukan di beberapa kecamatan di Kabupaten Aceh Utara yang terdapat kasus filariasis berdasarkan data Dinas Kesehatan Kabupaten Aceh Utara. Penelitian ini dilakukan pada tahun 2019. Jenis penelitian yang digunakan merupakan penelitian retrospektif dengan desain studi kasus kontrol (Case Control Study). Penelitian ini dilakukan dengan cara menentukan kelompok kasus dan kelompok kontrol, lalu mengukur paparan pada waktu yang lalu untuk melihat asosiasi antara penyakit dan paparan. ${ }^{11}$

Populasi dalam penelitian ini dibagi dalam dua kelompok yaitu populasi kasus, dan populasi control. Populasi kasus yaitu Semua orang yang dinyatakan menderita filariasis berdasarkan data di Dinas Kesehatan Kabupaten Aceh Utara tahun 2017 sebanyak 103 orang. Populasi control yaitu Semua orang yang dinyatakan bebas filariasis yang bertempat tinggal 
di desa yang sama dengan kelompok kasus dan tidak tinggal serumah dengan kelompok kasus, memiliki usia setara atau selisih 5 tahun, berjenis kelamin sama dan mempunyai faktor risiko sama dengan kelompok kasus.

Besaran sampel untuk penelitian kasus kontrol dihitung dengan rumus sebagai berikut: ${ }^{12}$

$$
\begin{aligned}
& \mathrm{P}_{1}=\frac{(\mathrm{OR}) \mathrm{P}_{2}}{(O R) \mathrm{P}_{2}+\left(1-\mathrm{P}_{2}\right)} \\
& \mathrm{n}=\frac{\mathrm{Z}^{2}{ }_{1-\alpha / 2}\left\{1 /\left[\mathrm{P} 1\left(1-\mathrm{P}_{1}\right)\right]+\left\{1 /\left[\mathrm{P}_{2}\left(1-\mathrm{P}_{2}\right)\right]\right\}\right.}{\{1 n(1-\varepsilon)\}^{2}}
\end{aligned}
$$

Keterangan:

$\mathrm{Z}^{2}{ }_{1-\alpha / 2} \quad$ : Statistik z pada standar distribusi normal, pada tingkat kemaknaan $95 \%(\alpha=0,05)$ untuk uji dua arah, sebesar 1,96

$\mathrm{P}_{1} \quad$ : Proporsi terpapar pada kelompok kasus

$\mathrm{P}_{2} \quad$ : Proporsi terpapar pada kelompok kontrol, sebesar 0,5 $(0,01-0,90)$

$\varepsilon \quad$ : Presisi/penyimpangan, sebesar $0,3(0,10-0,50)$

OR : Besar risiko paparan faktor risiko, sebesar $2(1,25-4,0)$

n : Besar sampel

Dari hasil perhitungan di atas, maka sampel penelitian didapat sebanyak 67 orang untuk tiap kelompok yaitu 67 orang untuk kelompok kasus dan 67 orang untuk kelompok control, sehingga total sampel dalam penelitian ini sebanyak 134 orang. Pengambilan sampel menggunakan metode proporsional random sampling.

Variable dependen dalam penelitian ini yaitu kejadian filariasis limfatik, sedangkan variabel independen yaitu faktor risiko perilaku dan faktor risiko lingkungan. Metode analisis data yang digunakan dalam penelitian ini meliputi:

1) Analisa Univariat

Data yang terkumpul diolah dan dianalisa secara deskriptif, disajikan dalam bentuk tabel distribusi frekuensi, gambar atau grafik.

2) Analisa Bivariat

Untuk mengetahui ada tidaknya hubungan dan kekuatan hubungan antara variabel bebas dengan variabel terikat. Uji statistik yang digunakan adalah chi square, pemakaian chi square karena data yang dianalisa dalam bentuk kategori berskala nominal.

3) Analisa Multivariat 
Analisa multivariat digunakan untuk mengetahui variable bebas yang paling berpengaruh terhadap variable terikat. Untuk mengetahui seberapa besar variabel bebas beresiko terhadap penularan filariasis limfatik, baik secara sendiri-sendiri (bivariat) maupun secara bersama-sama (multivariat). Untuk rancangan case control besar resiko relatif dicerminkan dengan angka odds ratio (OR) Odds ratio dianalisis pada rentang 95\% (95\% CI OR).

\section{HASIL PENELITIAN}

\section{Analisis Univariat}

1) Karakteristik responden

Tabel 1 Karakteristik responden berdasarkan jenis kelamin dan umur

\begin{tabular}{llcccccc}
\hline No & \multicolumn{1}{c}{ Karakteristik } & \multicolumn{2}{c}{ Kasus } & \multicolumn{2}{c}{ Kontrol } & \multicolumn{2}{c}{ Total } \\
\cline { 2 - 8 } & \multicolumn{1}{c}{ Responden } & Jumlah & $\%$ & Jumlah & $\%$ & Jumlah & $\%$ \\
\hline 1 & Jenis Kelamin & & & & & & \\
& Laki-laki & 33 & 49,37 & 33 & 49,37 & 66 & 49,25 \\
& Perempuan & 34 & 50,63 & 34 & 50,63 & 68 & 50,75 \\
& $\quad$ Jumlah & 67 & 100,00 & 67 & 100,00 & 134 & 100,00 \\
\multirow{2}{*}{2} & & & & & & \\
& Umur & 14 & 17,91 & 14 & 17,91 & 28 & 20,90 \\
& $35-50$ tahun & 45 & 68,66 & 45 & 68,66 & 90 & 67,16 \\
& $51-66$ tahun & 8 & 13,43 & 8 & 13,43 & 16 & 11,94 \\
& $67-82$ tahun & 67 & 100,00 & 67 & 100,00 & 134 & 100,00 \\
\hline & Jumlah & & & & & &
\end{tabular}

Dari tabel 1 di atas dapat dilihat bahwa dari keseluruhan sampel penelitian, berdasarkan jenis kelamin didapatkan bahwa penderita filariasis terbanyak pada jenis kelamin perempuan yaitu sebanyak 50,63\%. Sementara itu, berdasarkan umur didapatkan bahwa rentang umur 51-66 tahun paling banyak menderita filariasis yaitu sebanyak 68,66\%.

2) Karakteriktik lingkungan

Tabel 2 Karakteritik Responden Berdasarkan Lingkungan Fisik

\begin{tabular}{|c|c|c|c|c|c|c|c|}
\hline \multirow{2}{*}{ No } & \multirow{2}{*}{ Karakteristik Lingkungan Fisik } & \multicolumn{2}{|c|}{ Kasus } & \multicolumn{2}{|c|}{ Kontrol } & \multicolumn{2}{|c|}{ Total } \\
\hline & & $\mathrm{Jlh}$ & $\%$ & Jlh & $\%$ & $\mathrm{Jlh}$ & $\%$ \\
\hline \multirow[t]{4}{*}{1} & Penggunaan kawat kasa & & & & & & \\
\hline & $\mathrm{Ya}$ & 26 & 38,81 & 47 & 70,15 & 73 & 54,48 \\
\hline & Tidak & 41 & 61,19 & 20 & 29,85 & 61 & 45,52 \\
\hline & Jumlah & 67 & 100,00 & 67 & 100,00 & 134 & 100,00 \\
\hline \multirow[t]{4}{*}{2} & Keberadaan semak semak & & & & & & \\
\hline & $\mathrm{Ya}$ & 58 & 86,57 & 53 & 79,10 & 111 & 82,84 \\
\hline & Tidak & 9 & 13,43 & 14 & 20,90 & 23 & 17,16 \\
\hline & Jumlah & 67 & 100,00 & 67 & 100,00 & 134 & 100,00 \\
\hline
\end{tabular}




\begin{tabular}{lcccccc}
\hline 3 Kondisi plafon rumah & & & & & & \\
$\quad$ Baik & 9 & 13,43 & 18 & 26,87 & 27 & 20,15 \\
& 58 & 86,57 & 49 & 73,13 & 107 & 79,85 \\
Buruk & 67 & 100,00 & 67 & 100,00 & 134 & 100,00 \\
$\quad$ Jumlah & & & & & & \\
Keberadaan genangan air & 27 & 40,30 & 19 & 28,36 & 46 & 34,33 \\
$\quad$ Ya & 40 & 59,70 & 48 & 71,64 & 88 & 65,67 \\
$\quad$ Tidak & 67 & 100,00 & 67 & 100,00 & 134 & 100,00 \\
$\quad$ Jumlah & & & & &
\end{tabular}

Dari tabel 2 di atas menunjukkan bahwa berdasarkan lingkungan fisik jumlah rumah responden yang menggunakan kawat kasa pada ventilasi rumah sebanyak 54,48\%. Pemasangan kawat kasa pada ventilasi rumah lebih banyak pada rumah responden kelompok kontrol yaitu sebanyak 70,15\%. Tabel di atas juga menunjukkan bahwa sebahagian besar rumah responden dekat dengan keberadaan semak-semak yaitu sebesar 82,84\%, dimana rumah responden kelompok kasus lebih banyak yang berada dekat dengan semak-semak yaitu sebanyak $86,57 \%$. Sementara itu, berdasarkan kondisi plafon rumah, didapatkan bahwa 79,85\% rumah responden dengan kondisi plafon yang buruk. Dimana 86,57\% rumah kelompok kasus dengan kondisi plafon rumah yang buruk. Berdasarkan keberadaan genangan air di sekitar rumah responden ditemukan bahwa hanya 34,33\% rumah responden mempunyai genangan air di sekitar lingkungan rumahnya. Rumah kelompok kasus yang mempunyai genangan air sebanyak $40,30 \%$.

3) Karakteristik perilaku

Tabel 3 Karakteritik Responden Berdasarkan Perilaku

\begin{tabular}{|c|c|c|c|c|c|c|c|}
\hline \multirow{2}{*}{ No } & \multirow{2}{*}{ Karakteristik Perilaku } & \multicolumn{2}{|c|}{ Kasus } & \multicolumn{2}{|c|}{ Kontrol } & \multicolumn{2}{|c|}{ Total } \\
\hline & & $\mathrm{Jlh}$ & $\%$ & $\mathrm{Jlh}$ & $\%$ & $\mathrm{Jlh}$ & $\%$ \\
\hline \multirow[t]{5}{*}{1} & Penggunaan & & & & & & \\
\hline & Kelambu & & & & & & \\
\hline & Ya & 25 & 37,31 & 52 & 77,61 & 77 & 57,46 \\
\hline & Tidak & 42 & 62,69 & 15 & 22,39 & 57 & 42,54 \\
\hline & Jumlah & 67 & 100,00 & 67 & 100,00 & 134 & 100,00 \\
\hline \multirow[t]{4}{*}{2} & $\begin{array}{l}\text { Kebiasaan penggunaan obat } \\
\text { anti nyamuk }\end{array}$ & & & & & & \\
\hline & $\mathrm{Ya}$ & 24 & 35,82 & 44 & 65,67 & 68 & 50,75 \\
\hline & Tidak & 43 & 64,18 & 23 & 34,33 & 66 & 49,25 \\
\hline & Jumlah & 67 & 100,00 & 67 & 100,00 & 134 & 100,00 \\
\hline \multirow[t]{4}{*}{3} & $\begin{array}{l}\text { Kebiasaan keluar rumah pada } \\
\text { malam hari }\end{array}$ & & & & & & \\
\hline & $\mathrm{Ya}$ & 35 & 52,24 & 32 & 47,76 & 67 & 50,00 \\
\hline & Tidak & 32 & 47,76 & 35 & 52,24 & 67 & 50,00 \\
\hline & Jumlah & 67 & 100,00 & 67 & 100,00 & 134 & 100,00 \\
\hline 4 & menggantung & & & & & & \\
\hline
\end{tabular}




\begin{tabular}{lcccccc}
\hline pakaian di kamar & & & & & & \\
Ya & 60 & 89,55 & 49 & 73,13 & 109 & 81,34 \\
Tidak & 7 & 10,45 & 18 & 26,87 & 25 & 18,66 \\
Jumlah & 67 & 100,00 & 67 & 100,00 & 134 & 100,00 \\
\hline
\end{tabular}

Dari tabel 3 di atas menunjukkan bahwa berdasarkan perilaku, responden menggunakan kelambu pada saat tidur di malam hari sebanyak 57,46\%. Jumlah responden kelompok kontrol lebih banyak menggunakan kelampu pada saat tidur di malam hari yaitu sebanyak 77,61\%. Sebagian besar reponden mempunyai kebiasaan menggunakan obat anti nyamuk yaitu sebanyak 50,75\%. dimana jumlah responden kelompok kontrol lebih banyak mempunyai prilaku menggunakan obat anti nyamuk yaitu sebanyak 65,67\%. Jumlah responden yang mempunyai kebiasaan keluar rumah di malam hari sama dengan yang tidak mempunyai kebiasaan keluar rumah di malam hari. Akan tetapi jumlah kelompok kasus lebih banyak keluar rumah di malam hari yaitu sebanyak 52,24\%. Sementara itu, sebahagian besar responden mempunyai kebiasaan menggantung pakaian yaitu sebanyak 81,34\%. Dimana jumlah responden kelompok kasus lebih banyak mempunyai kebiasaan menggantung pakaian yaitu sebanyak $89,55 \%$.

\section{Analisis Bivariat}

1) Hubungan faktor risiko perilaku penggunaan kelambu dengan penularan filariasis limfatik di Kabupaten Aceh Utara

Tabel 4 Hubungan Faktor Risiko Prilaku Penggunaan Kelambu dengan Penularan Filariasis Limfatik

\begin{tabular}{|l|c|c|c|c|c|c|}
\hline \multirow{2}{*}{ Penggunaan Kelambu } & \multicolumn{2}{|c|}{ Kasus } & \multicolumn{2}{c|}{ Kontrol } & \multirow{2}{*}{$\begin{array}{c}\text { OR } \\
\text { value }\end{array}$} & (95\% CI) \\
\cline { 2 - 5 } & $\mathrm{N}$ & $\%$ & $\mathrm{~N}$ & $\%$ & value \\
\hline Ya & 25 & 37,31 & 52 & 77,61 & & 5,82 \\
\hline Tidak & 42 & 62,69 & 15 & 22,39 & \multirow{2}{*}{0,001} & \multirow{2}{*}{$(2,728-12,433)$} \\
\hline Jumlah & 67 & 100 & 67 & 100 & & \\
\hline
\end{tabular}

Berdasarkan tabel 4 di atas, sebanyak 62,69\% respoden kelompok kasus menggunakan kelambu pada saat tidur di malam hari, sedangkan pada kelompok kontrol hanya 22,39\%. Hasil analisis bivariat variabel kebiasaan menggunakan kelambu dengan penularan filariasis limfatik didapat nilai p 0,001 yang menunjukkan bahwa ada hubungan antara kebiasaan menggunakan kelambu dengan penularan filariasis limfatik di Kabupaten Aceh Utara. Hasil perhitungan odds ratio (OR) diperoleh nilai sebesar 5,82 (Confidence interval) (CI) 95\%= 2,728 - 12,433. Dari hasil tersebut dapat dikatakan bahwa orang yang tidak menggunakan kelambu pada waktu tidur mempunyai risiko penularan filariasis limfatik 5,82 kali lebih besar dibandingkan dengan orang yang menggunakan kelambu. 
2) Hubungan faktor risiko perilaku penggunaan obat anti nyamuk dengan penularan filariasis limfatik di Kabupaten Aceh Utara

Tabel 5 Hubungan Faktor Risiko Prilaku Penggunaan Obat Anti Nyamuk dengan Penularan Filariasis Limfatik

\begin{tabular}{|c|c|c|c|c|c|c|}
\hline \multirow{2}{*}{$\begin{array}{l}\text { Penggunaan Obat Anti } \\
\text { Nyamuk }\end{array}$} & \multicolumn{2}{|c|}{ Kasus } & \multicolumn{2}{|c|}{ Kontrol } & \multirow{2}{*}{$\begin{array}{c}\mathrm{P} \\
\text { value }\end{array}$} & \multirow{2}{*}{$\begin{array}{c}\text { OR } \\
(95 \% \mathrm{CI})\end{array}$} \\
\hline & $\mathrm{N}$ & $\%$ & $\mathrm{~N}$ & $\%$ & & \\
\hline $\mathrm{Ya}$ & 24 & 35,82 & 44 & 65,67 & \multirow{3}{*}{0,021} & \multirow{3}{*}{$\begin{array}{c}3,43 \\
(1,66-6,970)\end{array}$} \\
\hline Tidak & 43 & 64,18 & 23 & 34,33 & & \\
\hline Jumlah & 67 & 100 & 67 & 100 & & \\
\hline
\end{tabular}

Berdasarkan tabel 5 di atas, sebanyak 64,2\% responden kelompok kasus tidak menggunkan obat anti nyamuk, sedangkan pada kelompok kontrol sebanyak 34,3\%. Hasil analisis bivariat variabel kebiasaan menggunakan obat anti nyamuk dengan penularan filariasis limfatik didapat nilai p 0,001. Secara statistik dapat dikatakan ada hubungan antara kebiasaan menggunakan obat anti nyamuk dengan penularan filariasis limfatik di Kabupaten Ace Utara. Hasil perhitungan odds ratio (OR) diperoleh nilai sebesar 3,43 (Confidence interval) (CI) $95 \%=1,666-6,970$. Dari hasil tersebut dapat dikatakan bahwa orang yang tidak menggunakan obat anti nyamuk waktu tidur mempunyai risiko penularan filariasis limfatik 3,43 kali lebih besar dibandingkan dengan orang yang menggunakan obat anti nyamuk.

3) Hubungan faktor risiko perilaku keluar rumah pada malam hari dengan penularan filariasis limfatik di Kabupaten Aceh Utara

Tabel 6 Hubungan Faktor Risiko Prilaku Keluar Rumah Pada Malam Hari dengan Penularan Filariasis Limfatik

\begin{tabular}{|c|c|c|c|c|c|c|}
\hline \multirow{2}{*}{$\begin{array}{l}\text { Keluar Rumah pada } \\
\text { Malam Hari }\end{array}$} & \multicolumn{2}{|c|}{ Kasus } & \multicolumn{2}{|c|}{ Kontrol } & \multirow{2}{*}{$\begin{array}{c}\mathrm{P} \\
\text { value }\end{array}$} & \multirow{2}{*}{$\begin{array}{c}\text { OR } \\
(95 \% \mathrm{CI})\end{array}$} \\
\hline & $\mathrm{N}$ & $\%$ & $\mathrm{~N}$ & $\%$ & & \\
\hline $\mathrm{Ya}$ & 35 & 52,24 & 32 & 47,76 & \multirow{3}{*}{0,730} & \multirow{3}{*}{$\begin{array}{c}1,19 \\
(0,607-2,356)\end{array}$} \\
\hline Tidak & 32 & 47,76 & 35 & 52,24 & & \\
\hline Jumlah & 67 & 100 & 67 & 100 & & \\
\hline
\end{tabular}

Berdasarkan tabel 6 di atas, sebanyak 52,2\% responden kelompok kasus sering keluar rumah pada malam hari, sedangkan pada kelompok kontrol hanya sebanyak 47,8\%. Hasil analisis bivariat variabel kebiasaan keluar rumah malam pada hari dengan penularan filariasis limfatik didapat nilai $\mathrm{p} 0,730$. Secara statistik dapat dikatakan tidak ada hubungan antara kebiasaan keluar rumah pada malam hari dengan penularan filariasis limfatik di Kabupaten Aceh Utara. 
4) Hubungan faktor risiko perilaku menggantung pakaian dengan penularan filariasis limfatik di Kabupaten Aceh Utara

Tabel 7 Hubungan Faktor Risiko Prilaku Menggantung Pakaian di Dalam Rumah dengan Penularan Filariasis Limfatik

\begin{tabular}{|c|c|c|c|c|c|c|}
\hline \multirow{2}{*}{$\begin{array}{l}\text { Menggantung Pakaian di } \\
\text { Dalam Rumah }\end{array}$} & \multicolumn{2}{|c|}{ Kasus } & \multicolumn{2}{|c|}{ Kontrol } & \multirow{2}{*}{$\begin{array}{c}\mathrm{P} \\
\text { value }\end{array}$} & \multirow{2}{*}{$\begin{array}{c}\text { OR } \\
(95 \% \mathrm{CI})\end{array}$} \\
\hline & $\mathrm{N}$ & $\%$ & $\mathrm{~N}$ & $\%$ & & \\
\hline $\mathrm{Ya}$ & 60 & 89,55 & 49 & 73,13 & \multirow{3}{*}{0,042} & \multirow{3}{*}{$\begin{array}{c}4,923 \\
(1,938-23,765)\end{array}$} \\
\hline Tidak & 7 & 10,45 & 18 & 26,87 & & \\
\hline Jumlah & 67 & 100 & 67 & 100 & & \\
\hline
\end{tabular}

Berdasarkan tabel 7 di atas, 89,55\% responden kelompok kasus mempunyai kebiasaan menggantung pakaian di dalam rumah, sedangkan pada kelompok kontrol hanyak sebanyak 73,13\%. Hasil analisis bivariat variabel mempunyai kebiasaan menggantung pakaian di dalam rumah dengan penularan filariasis limfatik didapat nilai $\mathrm{p} 0,042$. Secara statistik dapat dikatakan ada hubungan antara kebiasaan menggantung pakaian di dalam rumah dengan penularan filariasis limfatik di Kabupaten Aceh Utara. Hasil perhitungan odds ratio (OR) diperoleh nilai sebesar 4,923 (Confidence interval) (CI) 95\% = 1,938 - 23,765. Dari hasil tersebut dapat dikatakan bahwa orang dengan perilaku kebiasaan menggantung pakaian di dalam rumah mempunyai risiko penularan filariasis limfatik 4,9 kali lebih besar dibandingkan dengan orang yang tidak mempunyai kebiasaan menggantung pakaian di dalam rumah.

5) Hubungan faktor risiko penggunaan kawat kasa dengan penularan filariasis limfatik di Kabupaten Aceh Utara

Tabel 8 Hubungan Faktor Risiko Penggunaan Kawat Kasa dengan Penularan Filariasis Limfatik

\begin{tabular}{|l|c|c|c|c|c|c|}
\hline \multirow{2}{*}{ Penggunaan Kawat Kasa } & \multicolumn{2}{|c|}{ Kasus } & \multicolumn{2}{c|}{ Kontrol } & \multirow{2}{*}{$\begin{array}{c}\text { OR } \\
\text { value }\end{array}$} & $(95 \% \mathrm{CI})$ \\
\cline { 2 - 5 } & $\mathrm{N}$ & $\%$ & $\mathrm{~N}$ & $\%$ & value \\
\hline Ya & 26 & 38,81 & 47 & 70,15 & & 3,71 \\
\hline Tidak & 41 & 61,19 & 20 & 29,85 & \multirow{2}{*}{0,001} & $\begin{array}{c}3,71 \\
(1,808-7,597)\end{array}$ \\
\hline Jumlah & 67 & 100 & 67 & 100 & & \\
\hline
\end{tabular}

Berdasarkan tabel 8 di atas, sebanyak 61,19\% responden kelompok kasus mempunyai ventilasi rumah yang tidak terpasang kawat kasa nyamuk, sedangkan pada kelompok kontrol hanya sebanyak 29,85\%. Hasil analisis bivariat variabel penggunaan kawat kasa ventilasi rumah dengan kejadian filariasis didapat nilai p 0,001. Secara statistik dapat dikatakan ada hubungan antara pemasangan kawat kasa pada ventilasi rumah dengan penularan filariasis di Kabupaten Aceh Utara. Hasil perhitungan odds ratio (OR) diperoleh nilai sebesar 3,71 (Confidence interval) $(\mathrm{CI}) 95 \%=1,808-7,597$. Dari hasil tersebut dapat dikatakan bahwa 
orang yang tinggal di rumah yang tidak terpasang kasa nyamuk pada ventilasi, mempunyai risiko penularan filariasis limfatik $3,71 \mathrm{kali}$ lebih besar dibandingkan dengan orang yang tinggal di rumah yang terpasang kasa nyamuk pada ventilasinya.

6) Hubungan faktor risiko keberadaan semak-semak dengan penularan filariasis limfatik di Kabupaten Aceh Utara

Tabel 9 Hubungan Faktor Risiko Keberadaan Semak-semak dengan Penularan Filariasis Limfatik

\begin{tabular}{|c|c|c|c|c|c|c|}
\hline \multirow{2}{*}{ Keberadaan Semak-semak } & \multicolumn{2}{|c|}{ Kasus } & \multicolumn{2}{|c|}{ Kontrol } & \multirow{2}{*}{$\begin{array}{c}\mathrm{P} \\
\text { value }\end{array}$} & \multirow{2}{*}{$\begin{array}{c}\text { OR } \\
(95 \% \mathrm{CI})\end{array}$} \\
\hline & $\mathrm{N}$ & $\%$ & $\mathrm{~N}$ & $\%$ & & \\
\hline $\mathrm{Ya}$ & 58 & 86,57 & 53 & 79,10 & \multirow{3}{*}{0,075} & \multirow{3}{*}{$\begin{array}{c}0,99 \\
(0,995-4,117)\end{array}$} \\
\hline Tidak & 9 & 13,43 & 14 & 20,90 & & \\
\hline Jumlah & 67 & 100 & 67 & 100 & & \\
\hline
\end{tabular}

Berdasarkan tabel 9 di atas, sebanyak 86,57\% responden kelompok kasus bertempat tinggal kurang dari $100 \mathrm{~m}$ dari keberadaan semak-semak, sedangkan pada kelompok kontrol sebanyak 79,10\%. Hasil analisis bivariat variabel keberadaan semak-semak disekitar rumah dengan penularan filariasis didapat nilai p 0,075. Secara statistik dapat dikatakan tidak ada hubungan antara keberadaan semak-semak disekitar rumah dengan penularan filariasis limfatik di Kabupaten Aceh Utara.

7) Hubungan faktor risiko kondisi plafon rumah dengan penularan filariasis limfatik di Kabupaten Aceh Utara

Tabel 10 Hubungan Faktor Risiko Kondisi Plafon dengan Penularan Filariasis Limfatik

\begin{tabular}{|l|c|c|c|c|c|c|}
\hline \multirow{2}{*}{ Kondisi Plafon Rumah } & \multicolumn{2}{|c|}{ Kasus } & \multicolumn{2}{c|}{ Kontrol } & \multirow{2}{*}{$\begin{array}{c}\text { OR } \\
\text { value }\end{array}$} & $(95 \%$ CI $)$ \\
\cline { 2 - 5 } & $\mathrm{N}$ & $\%$ & $\mathrm{~N}$ & $\%$ & valuen \\
\hline Baik & 9 & 13,43 & 18 & 26,87 & & 5,182 \\
\hline Buruk & 58 & 86,57 & 49 & 73,13 & \multirow{2}{*}{0,014} & $(1,339-20,058)$ \\
\hline Jumlah & 67 & 100 & 67 & 100 & & \\
\hline
\end{tabular}

Berdasarkan tabel 10 di atas, sebanyak 86,57\% reponden kelompok kasus mempunyai rumah dengan kondisi plafon yang buruk, sedangkan pada kelompok control hanya sebanyak $73,13 \%$. Hasil analisis bivariat variabel kondisi plafon rumah dengan kejadian filariasis didapat nilai $\mathrm{p} 0,014$ atau $\mathrm{p}<0,05$. Secara statistik dapat dikatakan ada hubungan antara kondisi plafon rumah dengan penularan filariasis di Kabupaten Aceh Utara. Hasil perhitungan odds ratio (OR) diperoleh nilai sebesar 5,182 (Confidence interval) (CI) 95\% $=1,339-$ 20,058. Dari hasil tersebut dapat dikatakan bahwa orang yang tinggal di rumah yang memiliki kondisi plafon yang buruk mempunyai risiko penularan filariasis limfatik 5,1 kali lebih besar dibandingkan dengan orang yang tinggal di rumah dengan kondisi plafon yang baik. 
8) Hubungan faktor risiko keberadaan genangan air dengan penularan filariasis limfatik di Kabupaten Aceh Utara

Tabel 11 Hubungan Faktor Risiko Keberadaan Genangan Air dengan Penularan Filariasis Limfatik

\begin{tabular}{|c|c|c|c|c|c|c|}
\hline \multirow{2}{*}{ Keberadaan Genangan Air } & \multicolumn{2}{|c|}{ Kasus } & \multicolumn{2}{|c|}{ Kontrol } & \multirow{2}{*}{$\begin{array}{c}\mathrm{P} \\
\text { value }\end{array}$} & \multirow{2}{*}{$\begin{array}{c}\text { OR } \\
(95 \% \mathrm{CI})\end{array}$} \\
\hline & $\mathrm{N}$ & $\%$ & $\mathrm{~N}$ & $\%$ & & \\
\hline $\mathrm{Ya}$ & 27 & 40,30 & 19 & 28,36 & \multirow{3}{*}{0,072} & \multirow{3}{*}{$\begin{array}{c}1,60 \\
(0,777-3,303)\end{array}$} \\
\hline Tidak & 40 & 59,70 & 48 & 71,64 & & \\
\hline Jumlah & 67 & 100 & 67 & 100 & & \\
\hline
\end{tabular}

Berdasarkan tabel 11 di atas, sebanyak 40,30\% responden kelompok kasus terdapat genangan air disekitar rumahnya, sedangkan pada kelompok kontrol hanya 28,36\%. Hasil analisis bivariat variabel genangan air disekitar rumah dengan penularan filariasis limfatik didapat nilai p 0,272. Secara statistik dapat dikatakan tidak ada hubungan antara keberadaan genangan air disekitar rumah dengan penularan filariasis di Kabupaten Aceh Utara.

\section{Analisis Multivariat}

Variabel potensial sebagai faktor risiko penularan filariasis yaitu Penggunaan kelambu, penggunaan obat anti nyamuk, penggunaan kawat kasa, menggantung pakaian, dan kondisi plafon rumah selanjutnya dilakukan analisis secara multivariat menggunakan regresi logistik. Karena pada penelitian ini menggunakan disain case control, maka dalam analisis regresi logistik digunakan metode forward/backward conditional. Hasil analisis dengan regresi logistik diperoleh hasil seperti pada tabel 12.

Tabel 12 Hasil analisis regresi logistik variabel potensial dengan penularan filariasis limfatik di Kabupaten Aceh Utara

\begin{tabular}{lccccc}
\hline \multicolumn{1}{c}{ Variabel } & \multirow{2}{*}{ B } & \multirow{2}{*}{ P Value } & \multirow{2}{*}{ OR } & \multicolumn{2}{c}{ 95\% C.I.for EXP(B) } \\
\cline { 5 - 6 } & & & & Lower & Upper \\
\hline Penggunaan kelambu & 1,772 & 0,010 & 5,880 & 1,514 & 22,835 \\
Penggunaan obat anti nyamuk & 1,750 & 0,057 & 5,757 & 2,384 & 13,899 \\
Penggunaan kawat kasa & 1,508 & 0,035 & 4,516 & 1,115 & 18,284 \\
Menggantung pakaian & 3,891 & 0,047 & 2,337 & 1,124 & 21,039 \\
Plafon rumah & 2,432 & 0,032 & 3,341 & 2,772 & 10,115 \\
\hline
\end{tabular}


Berdasarkan hasil analisis dengan regresi logistik (terhadap lima variabel potensial), seperti tampak pada tabel 12 ternyata hanya empat variabel yang menjadi faktor risiko penularan filariasis limfatik di Kabupaten Aceh Utara, yaitu penggunaan kelambu, penggunaan kawat kasa, menggantung pakaian, dan plafon rumah dengan koefisien regresi masing-masing: $1,773,1,508,1,772$ dan 1,450.

\section{PEMBAHASAN}

Hubungan faktor risiko perilaku dengan penularan filariasis limfatik di Kabupaten Aceh Utara

Hasil penelitian menunjukkan bahwa factor risiko perilaku menggunakan kelambu berhubungan dengan penularan filariasis limfatik di Kabupaten Aceh Utara, dimana orang yang tidak menggunakan kelambu pada waktu tidur mempunyai risiko penularan filariasis limfatik 5,82 kali lebih besar dibandingkan dengan orang yang menggunakan kelambu. Kebiasaan menggunakan kelambu pada waktu tidur secara teoritis mempunyai kontribusi untuk mencegah penularan filariasis, karena pada umumnya aktivitas menggigit nyamuk tertinggi pada malam hari. Menghindari diri dari gigitan nyamuk yaitu dengan menutup ruangan dengan kasa kawat, memakai kelambu pada tempat tidur, upaya yang dianjurkan sesuai dengan saran kementerian kesehatan, pada daerah yang bersiko tertulah filaria tidur menggunakan kelambu. Hasil penelitian ini sejalan dengan penelitian yang dilakukan oleh Depkes bahwa menghindari penyakit filaria tidur menggunakan kelambu baik kelambu biasa atau belambu berinsektisida (long lasting insecticide nets) adalah kelambu yang sudah dilapisi dengan anti nyamuk oleh pabrik kelambu. Kelambu ini tidak berbahaya bagi kesehatan manusia karena anti nyamuk yang melekat pada kelambu tersebut tidak dapat meracuni manusia. Pemakaian kelambu efektif dan berguna untuk mencegah kontak dengan nyamuk vektor filariasis yaitu Culex sp ketika tidur baik siang maupun malam hari sehingga mengurangi risiko tertular filariasis.Karena nyamuk Culex sp ini memiliki kebiasaan selain menggigit di luar rumah (eksofilik) juga menggigit di dalam rumah (endofilik) pada malam hari.Puncak menggigit nyamuk adalah pukul 01.00- 02.00 WIB. Hal ini sejalan dengan penelitian Ardias, dkk (2012) bahwa orang yang tidak memiliki kebiasaan menggunakan kelambu memiliki risiko 3,75 kali lebih besar tertular filariasis dibandingkan dengan orang yang menggunakan kelambu. ${ }^{13}$ 
Hasil penelitian menunjukkan bahwa faktor risiko perilaku menggunakan obat anti nyamuk berhubungan dengan penularan filariasis limfatik di Kabupaten Aceh Utara, dimana orang yang tidak menggunakan obat anti nyamuk waktu tidur mempunyai risiko penularan filariasis limfatik 3,43 kali lebih besar dibandingkan dengan orang yang menggunakan obat anti nyamuk. Berdasarkan hasil penelitian menunjukkan sebagian besar responden sudah menggunakan obat nyamuk berbagai jenis (semprot, oles, elektrik dan bakar), adapun yang tidak menggunakan dikarenakan kondisi rumah yang menurutnya sedikit nyamuk. Pemakaian obat nyamuk sebagai pengusir nyamuk dianggap lebih praktis dibandingkan kelambu.Terdapat alternatif lainnya yaitu menggunakan kipas angin dan minyak telon. Penggunaan obat nyamuk dapat meminimalisir risiko tertular filariasis. Hal ini sesuai dengan penelitian dari Windiastuti, dkk (2013) menunjukkan responden yang tidak menggunakan obat anti nyamuk mempunyai risiko menderita filariasis 6,167 kali lebih besar daripada yang menggunakan obat anti nyamuk. ${ }^{9}$

Hasil penelitian menunjukkan bahwa faktor risiko perilaku menggantung pakaian di dalam rumah berhubungan dengan penularan filariasis limfatik di Kabupaten Aceh Utara, dimana orang dengan perilaku kebiasaan menggantung pakaian di dalam rumah mempunyai risiko penularan filariasis limfatik 4,9 kali lebih besar dibandingkan dengan orang yang tidak mempunyai kebiasaan menggantung pakaian di dalam rumah. Pakaian yang digantung dapat menjadi sarang nyamuk.menggantung pakaian meningkatkan risiko untuk terkena gigitan nyamuk penular filariasis.Karena pakaian yang digantung merupakan tempat bersitirahat nyamuk setelah menghisap darah sehingga peluangkontak manusia dengan nyamuk vektor filariasis lebih besar. Hasil penelitian ini sesuai dengan penelitian Ardias, Setiani dan Hanani (2012) bahwa responden yang disekitar rumahnya terdapat tempat istirahat nyamuk (kandang ternak, semak-semak dan pakaian yang digantung) memiliki risiko menderita filariasis 4,480 kali lebih besar dibandingkan dengan responden yang disekitar rumahnya tidak terdapat tempat istirahat nyamuk. ${ }^{13}$

\section{Hubungan faktor risiko lingkungan dengan penularan filariasis limfatik di Kabupaten}

\section{Aceh Utara}

Hasil penelitian menunjukkan bahwa faktor risiko pemasangan kawat kasa pada ventilasi rumah berhubungan dengan penularan filariasis di Kabupaten Aceh Utara, dimana orang yang tinggal di rumah yang tidak terpasang kasa nyamuk pada ventilasi, mempunyai risiko penularan filariasis limfatik 3,71 kali lebih besar dibandingkan dengan orang yang tinggal di rumah yang terpasang kasa nyamuk pada ventilasinya. Pemasangan kawat kasa 
pada ventilasi akan menyebabkan semakin kecilnya kontak nyamuk yang berada di luar rumah dengan penghuni rumah, dimana nyamuk tidak dapat masuk ke dalam rumah. ${ }^{14}$ Penggunaan kawat kasa pada ventilasi rumah efektif menghalangi nyamuk untuk masuk ke dalam rumah sehingga terhindar dari gigitan nyamuk. Hal ini sesuai dengan penelitian yang dilakukan Juriastuti, dkk (2010), bahwa orang yang tidak memiliki kawat kasa di rumahnya berisiko 7,2 kali lebih besar menderita filariasis dibandingkan dengan yang menggunakan kawat kasa pada ventilasi rumah. ${ }^{15}$ Penelitian ini juga didukung penelitian lainya oleh Febrianto, dkk (2008) bahwa pemasangan kawat kasa pada ventilasi rumah sebagai proteksi terhadap gigitan nyamuk akan melindungi 7 kali dari risiko tertular filariasis. ${ }^{14}$

Hasil penelitian faktor risiko keberadaan semak-semak disekitar rumah tidak berhubungan dengan penularan filariasis limfatik di Kabupaten Aceh Utara. Vektor filariasis biasanya membutuhkan tempat yang lembab dan basah di luar rumah sebagai tempat istirahat pada siang hari. Orang dengan kondisi lingkungan biologi sekitar rumahnya terdapat semaksemak sebagai tempat resting place nyamuk akan meningkatkan risiko tertular filariasis 5,481 lebih besar dibandingkan yang tidak ada. Penting kiranya untuk dilakukan pembersihan rutin untuk mengurangi kelebatan semak-semak sehingga tidak dijadikan sebagai resting place nyamuk vektor filariasis. ${ }^{16}$

Hasil penelitian menunjuukkan bahwa faktor risiko kondisi plafon rumah berhubungan dengan penularan filariasis di Kabupaten Aceh Utara, dimana orang yang tinggal di rumah yang memiliki kondisi plafon yang buruk mempunyai risiko penularan filariasis limfatik 5,1 kali lebih besar dibandingkan dengan orang yang tinggal di rumah dengan kondisi plafon yang baik. Plafon rumah berguna untuk memisahkan antara genting dan ruangan agar tidak berhubungan secara langsung. Sehingga, keberadaan plafon penting untuk agar nyamuk tidak leluasa masuk rumah melalui celah-celah genting. Responden dengan keadaan plafon yang buruk di rumah akan lebih berisiko mengalami kejadian filariasis 6,3 kali dibandingkan responden dengan keadaan plafon yang baik. ${ }^{17}$

\section{KESIMPULAN}

1. Perilaku kebiasaan menggunakan kelambu mempunyai hubungan dengan penularan filariasis limfatik di Kabupaten Aceh Utara.

2. Perilaku kebiasaan menggunakan obat anti nyamuk mempunyai hubungan dengan penularan filariasis limfatik di Kabupaten Aceh Utara.

3. Perilaku kebiasaan menggantung mempunyai hubungan dengan penularan filariasis limfatik di Kabupaten Aceh Utara. 
4. Penggunaan kawat kasa pada ventilasi mempunyai hubungan dengan penularan filariasis limfatik di Kabupaten Aceh Utara.

5. Keberadaan plafon rumah mempunyai hubungan dengan penularan filariasis limfatik di Kabupaten Aceh Utara.

\section{REFERENSI}

1. Chin, J., 2006. Manual Pemberantasan Penyakit Menular. Editor: dr. I. Nyoman Kandun, Edisi 17 Cetakan II, Jakarta: Infomedika.

2. Centers for Desease Control and Prevention. Lymphatic Filariasis. https://www.cdc.gov/parasites/lymphaticfilariasis/

3. Sarungu Y, Onny Setiani, Sulistiyani, 2012. Faktor Risiko Lingkungandan Kebiasaan Penduduk Berhubungan Dengan Kejadian Filariasis di Distrik Windesi Kabupaten Kepulauan Yapen Provinsi Papua. Jurnal Kesehatan Lingkungan Indonesia. Vol. 11, No.1.

4. Kemenkes RI, 2015. Menuju Eliminasi Filariasis 2020. Jakarta: Pusat Data dan Informasi Kementrian Kesehatan RI.

5. Dinas Kesehatan Provinsi Aceh, 2015. Profil Kesehatan Provinsi Aceh.

6. Dinas Kesehatan Kabupaten Aceh Utara, 2017. Bidang Pencegahan dan Pemberantasan Penyakit Program Filariasis.

7. Mardiana, Enny W., dan Dian P., 2011. Faktor yang Mempengaruhi Kejadian Filariasis di Indonesia (Data Riskesdas 2007). Jurnal Ekologi Kesehatan, Vol. 10, No. 2.

8. Notoatmodjo S. 2007. Promosi kesehatan dan ilmu perilaku. Rineka Cipta: Jakarta.

9. Windiastuti, I.A., Suhartono, Nurjazuli, 2013. Hubungan Kondisi Lingkungan Rumah, Sosial Ekonomi, dan Perilaku Masyarakat dengan Kejadian Filariasis di Kecamatan Pekalongan Selatan Kota Pekalongan. Jurnal Kesehatan Lingkungan Indonesia. Vol. 12, No.1.

10. Hayati, N., 2015. Eksistensi Penggunaan Wi-Fi di Warung Kopi Di Kota Banda Aceh. Jurnal Al-Ijtimaiyyah. Vol. 1, No. 1.

11. Murti, B. 2003. Prinsip dan metode Riset Epidemiologi. Edisi Kedua Jilid Pertama. Yogyakarta: Gadjah Mada University Press

12. Lemeshow, S., dkk. 1997. Besar Sampel Dalam Penelitian Kesehatan. Yogyakarta: Gadjah Mada University Press.

13. Ardias, Setiani, O., dan Hanani, Y. 2012. Faktor Lingkungan dan Perilaku Masyarakat yang Berhubungan dengan Kejadian Filariasis di Kabupaten Sambas. Jurnal Kesehatan Lingkungan Indonesia. 11 (2): 199-207

14. Febrianto, B., Maharani, A., dan Widiarti. 2008. Faktor Risiko Filariasis di Desa Samborejo Kecamatan Tirto Kabupaten Pekalongan Jawa Tengah. Buletin Penelitian Kesehatan. 36 (2): 48-58

15. Juriastuti, P., Maya, I., Made, D., Dewi, S., 2010. Faktor Risiko Kejadian Filariasis di Kelurahan Jati Sampurna", Makara, Kesehatan, Vol. 14, No. 1.

16. Sipayung, M., Wahjuni, C.U., dan Devy, S.R.. 2014. Pengaruh Lingkungan Biologi dan Upaya Pelayanan Kesehatan Terhadap Kejadian Filariasis Limfatik di Kabupaten Sarmi. 
Jurnal Berkala Epidemiologi. 2 (2): 263-273.

17. Syuhada Y, Nurjazuli, \& Nur EW, 2012. Studi Kondisi Lingkungan Rumah dan Perilaku Masyarakat Sebagai Faktor Risiko Kejadian Filariasis di Kecamatan Buaran dan Tirto Kabupaten Pekalongan. Jurnal Kesehatan dan Lingkungan Indonesia. Vol. 2, No 1. 